\title{
DETERMINATION OF MECHANICAL AND FUNCTIONAL PROPERTIES BY CONTINUOUS VERTICAL CAST NiTi ROD
}

\author{
DOLOČITEV MEHANSKIH IN FUNKCIONALNIH LASTNOSTI \\ VERTIKALNO KONTINUIRNO LITE NiTi PALICE
}

\author{
Aleš Stambolić1,2, Monika Jenkoo ${ }^{1,2}$, Aleksandra Kocijan¹, Borut Žužek¹, Damjana Drobne ${ }^{3}$, \\ Rebeka Rudolf ${ }^{4,5}$ \\ ${ }^{1}$ Institute of Metals and Technology, Lepi pot 11, 1000 Ljubljana, Slovenia \\ ${ }^{2}$ Jožef Stefan International Postgraduate School, Jamova cesta 39, 1000 Ljubljana, Slovenia \\ ${ }^{3}$ Biotechnical Faculty, Department of Biology, Večna pot 111, 1000 Ljubljana, Slovenia \\ ${ }^{4}$ University of Maribor, Faculty of Mechanical Engineering, Smetanova ulica 17, 2000 Maribor, Slovenia \\ 5Zlatarna Celje d.o.o., Kersnikova ulica 19, 3000 Celje, Slovenia \\ ales.stambolic@imt.si
}

Prejem rokopisa - received: 2018-02-26; sprejem za objavo - accepted for publication: 2018-08-23

doi:10.17222/mit.2018.030

\begin{abstract}
This article presents the information of the microstructure and methods for determination of mechanical and functional properties of the Continuous Vertical Cast (CVC) NiTi rod. We prepared special samples (discs, cylinders). The results of the microhardness measurements with HV0.1 show the average Vickers hardness value 583 HV0.1 in the cross-section of the CVC NiTi rod measured from the edge toward the middle of CVC NiTi rod. The results show that Vickers hardness slightly increases towards the center of the rod as a consequence of the formatted microstructure. The results of the tensile test show a typical curve for brittle materials. The obtained results indicate that the CVC NiTi rod does not pass into a non-linear plastic region. Therefore, CVC NiTi rod is unsuitable for strain hardening. The results of the compressive test also follow the conclusions that CVC NiTi rod is brittle material. Fracture of the CVC NiTi rod sample occurs before the material enters the plastic deformation region. The cytocompatibility of the CVC NiTi rod was tested with the submersion of the samples to the HUVEC cell solution, where HUVEC cells adhered to the samples surface. A commercial NiTi alloy was used to monitor the cytocompatibility. The results show that the number of adhered HUVEC cells on the samples surface of CVC NiTi rod is smaller than on commercial NiTi. The number of dead HUVEC cells on the samples surface of CVC NiTi rod is slightly larger than on commercial NiTi. The proportion of viable HUVEC cells on the samples surface of CVC NiTi rod is 96,6\%, while on commercial NiTi $98,4 \%$. Keywords: CVC NiTi rod, hardness, mechanical properties, cytocompatibility
\end{abstract}

$\mathrm{V}$ članku je podana informacija o mikrostrukturi in metodah za določitev mehanskih in funkcionalnih lastnosti vertikalno-kontinuirno lite (CVC) NiTi palice. Pripravljeni so bili posebni vzorci (diski, valji). Rezultati meritev mikrotrdote HV0.1 kažejo povprečno vrednost trdote $v$ prečnem prerezu CVC NiTi palice, merjeno od roba proti sredini, 583 HV0.1. Vrednost trdote rahlo narašča proti sredini palice in je posledica nastale mikrostrukture. Rezultati nateznega preizkusa kažejo značilno krivuljo za krhke materiale in nakazujejo, da CVC NiTi palica ne preide v nelinearno plastično območje. Zaradi tega je CVC NiTi palica neprimerna za deformacijsko utrjevanje. Tudi rezultati tlačnega preizkusa sledijo ugotovitvam, da CVC NiTi palica spada med krhke materiale. Testirali smo citokompatibilnost CVC NiTi palice z izpostavljenostjo vzorcev raztopini HUVEC celic, kjer so se le-te adhezirale na površini vzorcev. HUVEC celice so tipične žilne celice, nahajajo se predvsem v venah. Za kontrolni material pri citokompatibilnosti je bila uporabljena komercialna NiTi zlitina. Rezultati kažejo, da je število adheziranih celic na površini vzorca CVC NiTi palice nekoliko nižja kot na komercialni NiTi zlitini. Śtevilo mrtvih HUVEC celic na površini vzorca CVC NiTi palice je nekoliko višja kot na komercialni NiTi zlitini. Delež živih celic na površini vzorca CVC NiTi palice je 96,6\%, medtem ko je na komercialni NiTi 98,4\%.

Ključne besede: CVC NiTi palica, trdota, mehanske lastnosti, citokompatibilnost

\section{INTRODUCTION}

Nitinol is a group of nearly equi-atomic alloys composed of nickel and titanium. It exhibits a unique combination of good functional properties and a high mechanical strength, such as superelasticity and a shape-memory effect, good corrosion resistance in a chloride environment, an unusual combination of strength and ductility, high tendency for self-passivation, paramagnetic properties, high fatigue strength, low Young's modulus and excellent bio-mechanical compatibility. ${ }^{1-7}$

This alloy was developed in the 1970s and its properties have enabled its use, especially for biomedical purposes, first in orthodontic treatments, and later on in cardiovascular surgery for stents, guide wires, filters, etc., in orthopedic surgery for various staples and rods, and in maxillofacial and reconstructive surgery. In addition to bioengineering, nitinol has been used in aerospace, automotive, marine, chemical industries, civil and structural engineering. ${ }^{1-7}$

Biocompatible materials can be defined as synthetic or natural biomaterials that are continuously or occasionally in contact with body fluids and can partially or totally replace any failing tissue, organ or function of the body in order to improve the quality of life of the individual. To successfully employ implants in the human body, a suitable level of tolerance of the material used 
within the living organism is required. ${ }^{8-10}$ The main problem of nitinol's biocompatibility is chemical composition and consequently high Ni content. Ni releasing can induce toxic, allergic and hypersensitive reactions or tissue necrosis after long term implantation. Leaching of $\mathrm{Ni}$ can arise when a strongly acidic fluid attacks the surface of the alloy. This corrosion is accompanied by nickel release from an implant into the surrounding body fluid and tissue, which can enhance an allergic reaction in a sensitive organism.

Second, corrosion can cause pitting and a reduction of mechanical performance of an implant. In an extreme case, an implant broken due to corrosion might produce sharp fragments that are dangerous for the surrounding tissue. To prevent corrosion and consequently Ni release, a coating of appropriate thickness must be formed on the NiTi surface. Titanium oxide coatings are useful enough to suppress nickel ions outleaching. ${ }^{11-15}$

The production of CVC NiTi rod was discussed in our previous paper. ${ }^{16}$ In this article we present the methods and approaches for determination of hardness and mechanical properties of as-cast CVC NiTi rod (as tensile, compressive and bending tests). Further, the comparison of CVC NiTi rod cytocompatibility with the commercially available nitinol in the form of rolled sheet was tested.

\section{EXPERIMENTAL PART}

\subsection{Sample preparation}

For microstructure investigation and cytocompatibility testing of the CVC NiTi rod was cut transversally in the disc shape with the diameter of the rod (approximately $11 \mathrm{~mm}$ ) and a width of $1 \mathrm{~cm}$ (Figure 1). For this purpose, an Accutom 50 (IMT, Ljubljana, Slovenia) electronic saw was used for precision cutting. Commercial NiTi, which was in the rolled state in the form of sheets with width of $1.5 \mathrm{~mm}$, was cut to circles with diameter of $10 \mathrm{~mm}$ and width of $1.5 \mathrm{~mm}$ using water jet cutter. For easier polishing, the samples were then hotpressed into Bakelite. Mechanical polishing was performed on Struers Abramin apparatus (IMT, Ljubljana, Slovenia). The grinding was performed with 320-grit SiC abrasive paper, mechanical polishing with MD-Largo

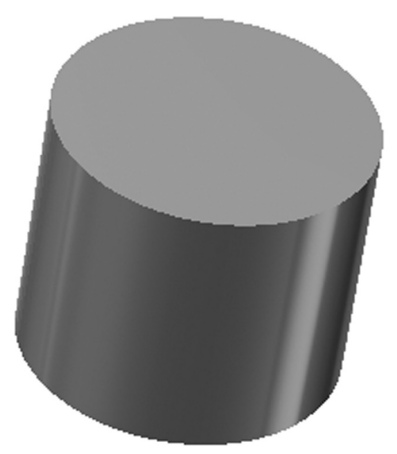

Figure 1: Disc sample for cytocompatibility measurement discs with $9 \mu \mathrm{m}$ diamond suspension and with peroxide grains in a chemically aggressive suspension - OP-S (colloidal silica). At the end samples were cleaned with detergent, well washed with water and put in an ultrasound bath in alcohol. For the microstructure characterization, samples were then etched with Kroll's reagent $(3 \mathrm{~mL} \mathrm{HF}, 6 \mathrm{~mL} \mathrm{HNO} 3$ and $100 \mathrm{~mL}$ of distilled water).

The chemical composition of CVC NiTi rod and commercial $\mathrm{NiTi}$ was measured using Inductively Coupled Plasma Optical Emission Spectroscopy ICP-OES (Agilent 720, IMT, Ljubljana, Slovenia).

Microstructure investigation of NiTi discs was performed using Scanning Electron Microscopy - Thermal Field Emision SEM JEOL JSM-6500F, equipped with Energy-dispersive X-ray spectroscopy (EDS), Wavelength-dispersive X-ray spectroscopy (WDS) and Electron backscatter diffraction (EBSD) analytical techniques (IMT, Ljubljana, Slovenia).

\subsection{Hardness and mechanical properties}

The hardness of the CVC NiTi rod was measured by Vickers. For this purpose, the CVC NiTi rod was cut transversally. Vickers hardness was measured in multiple points from the end of the rod to the center (radius) of the rod. Vickers hardness was performed on Instron Tukon 2100B (IMT, Ljubljana, Slovenia). The selected load was HV0.1, which means that a force of $0.98 \mathrm{~N}$ was used.

The tensile test samples were turned according to the B8 $\times 40$ standard (Figure 2a). The diameter of the specimens was $8 \mathrm{~mm}$, and their length was $40 \mathrm{~mm}$, and an M10 thread was used. The compressive test samples were turned into cylinders with a diameter of $10 \mathrm{~mm}$ and a height of $12 \mathrm{~mm}$ (Figure 2b). Tensile and compressive tests were accomplished at room temperature $\left(20 \pm 0.5{ }^{\circ} \mathrm{C}\right)$. Tests were performed on INSTRON 1255, $500 \mathrm{kN}$ device (IMT, Ljubljana, Slovenia). Preload force was
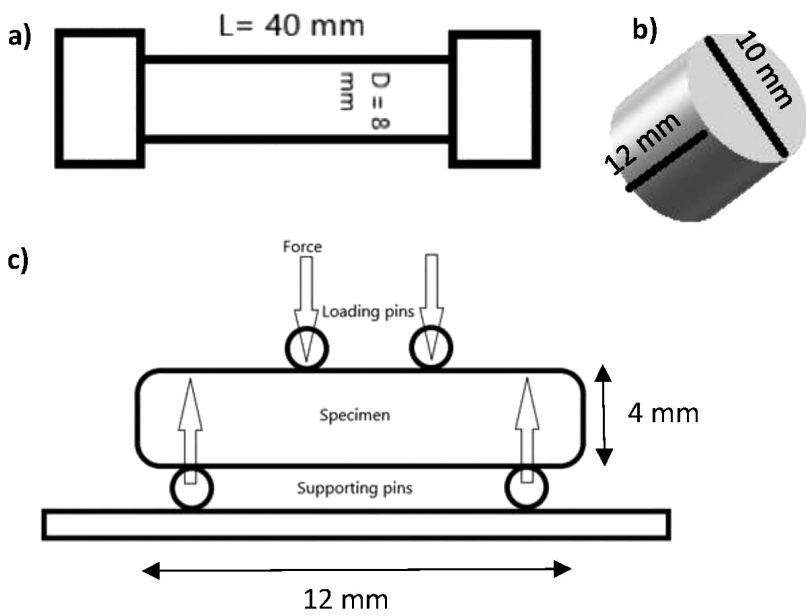

Figure 2: Schematic presentation of characteristic samples for: a) tensile test, b) compressive test and c) 4-point bending test 
$1 \mathrm{kN}$ and the velocity of deformation increase was $0.00025 \mathrm{~s}^{-1}$ in tension and in compression the preload force was $1 \mathrm{kN}$ and the compression velocity was $2 \mathrm{~mm} / \mathrm{min}$.

The 4-point bending test specimens were turned into cylinders with diameter of $4 \mathrm{~mm}$ and length of $12 \mathrm{~mm}$ (Figure 2c). The 4-point bending test was accomplished at room temperature $\left(19{ }^{\circ} \mathrm{C}\right)$. Tests were performed on AMSLER device (IMT, Ljubljana, Slovenia). The preload force was $0.0125 \mathrm{kN}$ and bending velocity was $0.5 \mathrm{~mm} / \mathrm{min}$.

\subsection{Cytocompatibility}

Human Umbilical Vein Endothelial Cells (HUVEC cells) were cultured in Dulbecco's modified Eagle's medium, in which 4-mM L-glutamine and $10 \%$ (v/v) foetal bovine serum (FBS) was added. Cells were grown at $37{ }^{\circ} \mathrm{C}$ in a humidified atmosphere with $5 \% \mathrm{CO}_{2}$ and were routinely passaged twice a week.

Sterile samples were aseptically put into the 12-well plates and then the cells were seeded into each well $\left(2 \times 10^{4}\right.$ cells $\left./ \mathrm{cm}^{2}\right)$. After a 24 -hour incubation, allowing the cells to adhere, the cells on the samples were rinsed with Dulbecco's Phosphate-Buffered Saline (to remove any floating, unattached cells) and stained with $2 \mu \mathrm{g} / \mathrm{mL}$ Hoechst 33342 and $2 \mu \mathrm{g} / \mathrm{mL}$ Propidium iodide for 20 min. Hoechst 33342 stains nuclei of all cells blue, while Propidium iodide stains nuclei of dead cells red. Stained cells that were adhered to the samples were observed with a fluorescent microscope Axio Imager.Z1 (Biotechnical Faculty - Department of Biology, Ljubljana, Slovenia) immediately after the staining. For each sample, several representative pictures at $25 \times$ and $100 \times$ magnifications were taken. The pictures were processed by the use of Image J $1.46 \mathrm{r}$ software, where the number of all attached cells (based on the number of blue nuclei) and the number of dead cells (based on the number of red nuclei) were evaluated.

After microscopic observation, samples with attached cells were inserted into the Karnovsky fixative, consisting of $2.5 \%$ glutaraldehyde and $0.4 \%$ paraformaldehyde in 1-M Na-phosphate buffer $\left(\mathrm{NaH}_{2} \mathrm{PO}_{4} \cdot 2 \mathrm{H}_{2} \mathrm{O}\right.$ and $\mathrm{Na}_{2} \mathrm{HPO}_{4} \cdot \mathrm{H}_{2} \mathrm{O}$ ). After $3 \mathrm{~h}$ incubation at room temperature, fixative was removed and samples were washed for $3 \times 10$ min with 1-M Na-phosphate buffer.



Figure 3: CVC NiTi rod
The post-fixation of samples was accomplished by $1 \%$ osmium tetroxide $(\mathrm{OsO} 4)$ for $60 \mathrm{~min}$, followed by washing in distilled $\mathrm{H}_{2} \mathrm{O}(3 \times 10 \mathrm{~min})$.

After the cells were fixed, images of cells on the surface of the samples were recorded with light microscopy Microphot FXA (IMT, Ljubljana, Slovenia). The proportion of the occupied surface with cells was measured using optical microscopic images and the computer software analySIS.

\section{RESULTS AND DISCUSSION}

\subsection{Microstructure of as-cast CVC NiTi rod}

Using CVC, a $3 \mathrm{~m}$ long rod with diameter of approximately $11 \mathrm{~mm}$ was obtained (Figure 3). The rod was silver coloured with visible periodic marks on its surface. ICP-OES analysis for the first attempt of CVC NiTi rod showed a constant material composition of $x_{\mathrm{Ni}}=59.8 \%$, $x_{\mathrm{Ti}}=38.9 \%, x_{\mathrm{C}}=0.3 \%$ and approximately $x_{\mathrm{Fe}}=1 \%$.

The microstructure of our CVC NiTi rod (Figure 4) is dendritic, with a radial orientation of the grains. The microstructure changes along the rod radius, and from a distance from the shell of a rod, it passes from finegrained to rough with heavily expanded dendritic branches and a greater proportion of the interdendritic eutectic. In the microstructure there are no visible defects such as cracks and other type of porosity.

Secondary electrons image (Figure 4) shows typical dendritic structure that is solidified primarily (NiTi phase). At the eutectic temperature $\left(1118{ }^{\circ} \mathrm{C}\right)$ typical lamellar eutectic structure $\left(\mathrm{NiTi}+\mathrm{TiNi}_{3}\right)$ is solidified from the residue of the melt. All the phases were confirmed using EBSD analysis.

\subsection{Microstructure of commercial nitinol}

The secondary electrons image of the nitinols crosssection (Figure 5) reveals a relatively microstructure that

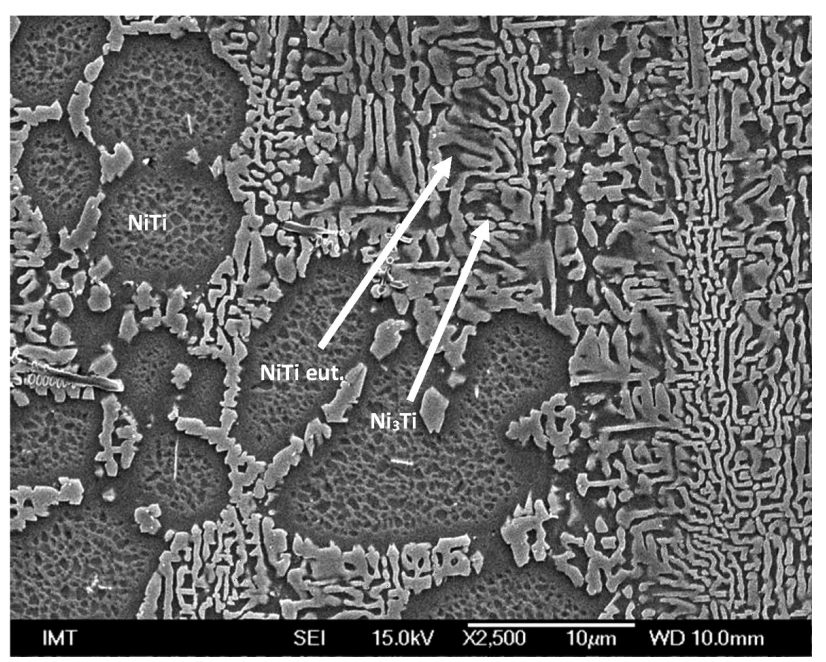

Figure 4: Secondary electron image at 2500x magnification of CVC NiTi rod 


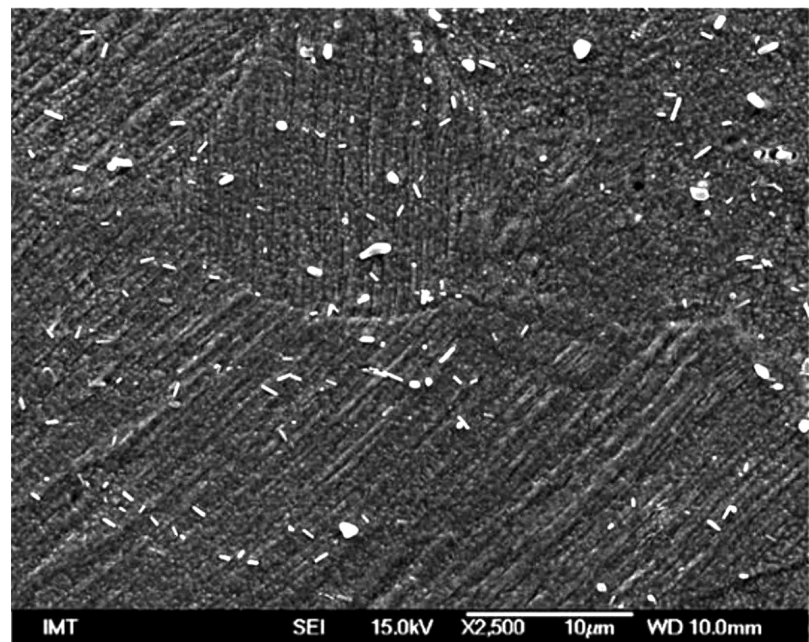

Figure 5: SE image at 2500× magnification of commercial nitinol

is characteristic for materials that were produced by rolling processes, since it is possible to notice a characteristic texture. Grains are almost the same size (about $20 \mu \mathrm{m})$, grain boundaries are clearly noticeable. Commercial nitinol consist of 2 phases. The EDS analysis showed that the prevailing phase (dark phase) is $\mathrm{NiTi}$, containing $x_{\mathrm{Ni}}=50 \%$ and $x_{\mathrm{Ti}}=50 \%$. The second phase is carbon and titanium rich phase (bright phase $-x_{\mathrm{C}}=$ $33.3 \%, x_{\mathrm{Ti}}=40.1 \%, x_{\mathrm{Ni}}=26.6 \%$ ).

The chemical composition of commercial NiTi, measured with ICP-OES analysis, is $x_{\mathrm{Ni}}=50.1 \%, x_{\mathrm{Ti}}=$ $49.89 \%$ and $x_{\mathrm{C}}<300 \mu \mathrm{g} / \mathrm{g}$.

\subsection{Hardness}

The most basic information about material is hardness. The cooling of CVC NiTi rod during drawing was held perpendicular to the drawing direction. The lowest temperature was on the mould walls or in the edge of CVC NiTi rod and was rising from circumference of CVC NiTi rod to the middle of CVC NiTi rod. In this manner we were interested in how the difference in the cooling temperature between the edge and the middle of CVC NiTi rod affects the hardness of the CVC NiTi rod. The hardness was measured in the CVC NiTi rod cross-section in its radius (from the edge of CVC NiTi rod to the middle of CVC NiTi rod).

As can be seen from diagram in Figure 6, the hardness of CVC NiTi rod is very constant in the direction of its radius. On the edge (0) of CVC NiTi rod the hardness is app. $550 \mathrm{HV}$ and the hardness value is then slightly increasing and alternating to the middle of the $\operatorname{rod}(\mathrm{D} / 2)$, where the hardness value is app. $600 \mathrm{HV}$. It can be concluded that the difference in temperature during cooling between the edge and the middle of CVC NiTi rod does not affect the hardness significantly. As we used a smaller tip to measure hardness, thus the differences in measured values of the hardness can be greater as the tip captures a smaller area. ${ }^{17}$ The length of indentation

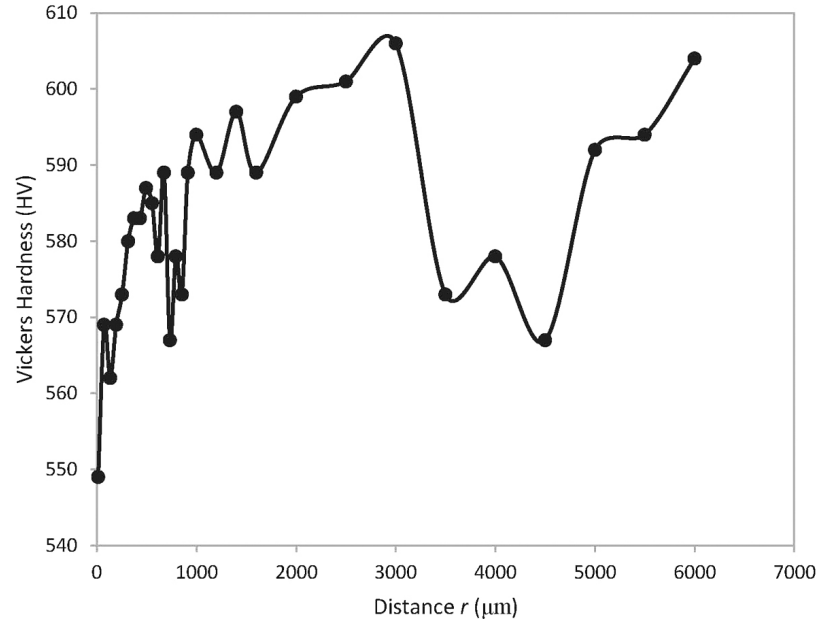

Figure 6: Diagram of Vickers hardness for CVC NiTi rod with the distance $r$

diagonal of used pyramid tip is about $13 \mathrm{~nm}$ long which means that when the hardness value is smaller, the tip makes indentation in an area where the dendrite is the prevailing phase. When the hardness value is larger, the tip makes indentation in a lamellar area and larger value is a consequence of harder $\mathrm{Ni}$ rich phase $\left(\mathrm{Ni}_{3} \mathrm{Ti}\right)$.

Material with hardness 550-600 HV can be assumed to be very hard. Motemani et al. ${ }^{18}$ measured the hardness of $50.7 \mathrm{NiTi}$ to be over $500 \mathrm{HV}$ when it was cooled rapidly with water, while the same material had hardness below $400 \mathrm{HV}$ if it was cooled slowly in furnace. Also higher Ni content means higher hardness. ${ }^{19}$ From this it can be concluded that over $550 \mathrm{HV}$ hardness of CVC NiTi rod is comprehensible due to its high Ni content $\left(x_{\mathrm{Ni}}\right.$ $=60 \%$ ) and fast water cooling during drawing.

\section{MECHANICAL PROPERTIES}

\subsection{Tensile test}

The picture of test specimens before and after the tensile test is seen in Figure 7. The fracture of test specimens occurred in the thread part where the test specimens are the weakest. Also the fracture was typically brittle (no neck has occurred).

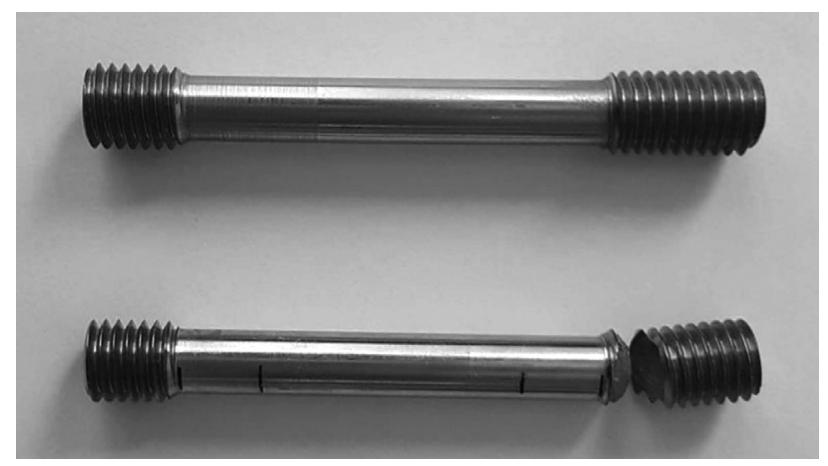

Figure 7: A test specimen of CVC NiTi rod before and after the tensile test 


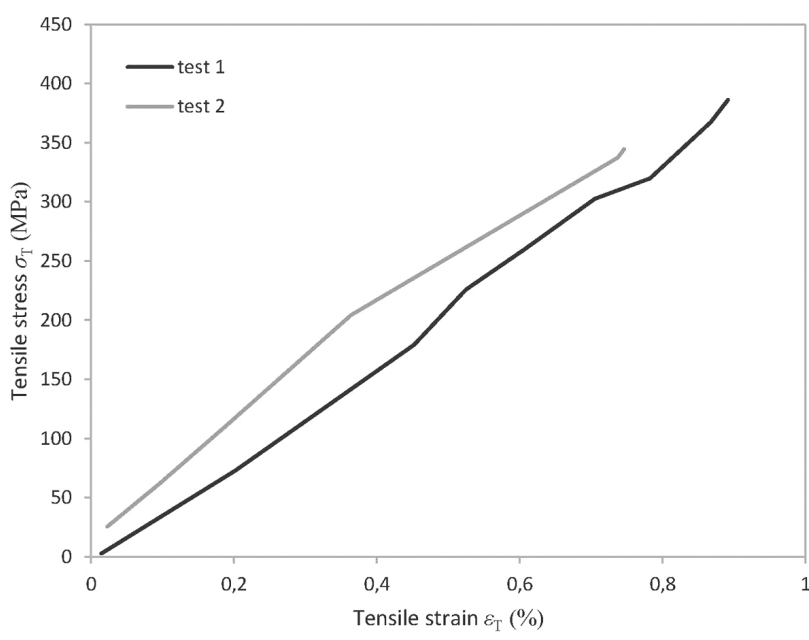

Figure 8: Stress-strain curve for tensile test of both test specimens of CVC NiTi rod

The tensile test diagram (Figure 8) shows a typical curve for brittle materials. Test 1 has a fracture tension, $\sigma_{\mathrm{T}, \mathrm{u}}$, of $388 \mathrm{MPa}$, a fracture strain, $\varepsilon_{\mathrm{T}, \mathrm{u}}$, of $0.9 \%$, and an elastic modulus in tension, $E_{\mathrm{m}, \mathrm{T}}$, of $40 \mathrm{GPa}$, while test 2 has a fracture tension of $347 \mathrm{MPa}$, a fracture strain of $0.8 \%$ and an elastic modulus in tension of $44 \mathrm{GPa}$. Both curves have a fairly linear shape up to the fracture. This means that the entire curves are located in an elastic region where the deformations are completely recoverable upon removal of the load. Such a diagram does not have a non-linear plastic region where deformations become permanent. If the material is sufficiently ductile, tensile stress can also greatly increase with high plastic deformation. CVC NiTi rod does not reach the plastic deformation and is thus unsuitable for strain hardening.

The obtained results correspond to the literature, ${ }^{18-20}$ where the authors determined that the brittleness of the as-cast NiTi alloy is mainly influenced by the high cooling rate of the alloy and its higher nickel content. If the as-cast NiTi alloy is furnace cooled or later hot worked, it also shows ductile properties.

\subsection{Compressive test}

In contrast to the tensile test, where the specimen withstands tensile loads and is thus elongated, by the

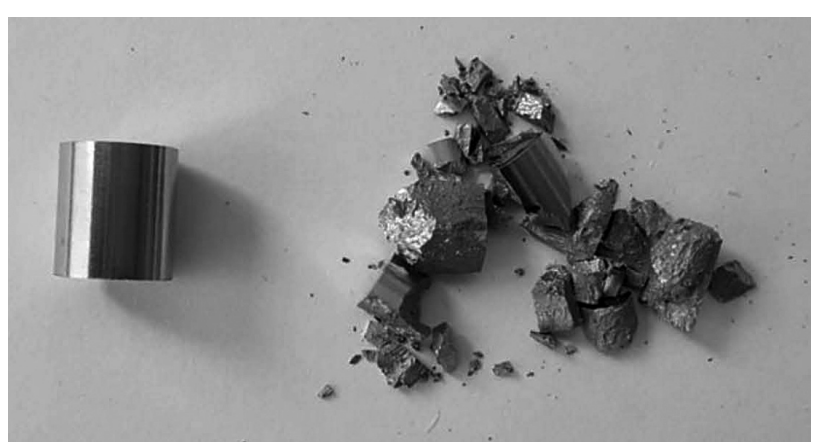

Figure 9: A test specimen of CVC NiTi rod before and after compressive test



Figure 10: Stress-strain curve for compressive test of both test specimens of CVC NiTi rod

compressive test the specimen resists to compressive strength and is thus pushed together. Figure 9 shows the specimen before and after the compressive test. Before the test, we had a cylinder-shaped specimen that was crushed to a large number of small pieces after the achieved ultimate compressive strength.

The diagram in Figure $\mathbf{1 0}$ shows the curves of brittle material in the compressive test. Test 1 has the ultimate compressive strength, $\sigma_{\mathrm{C}, \mathrm{u}}$, of $2350 \mathrm{MPa}$, the ultimate compressive strain, $\varepsilon_{\mathrm{C}, \mathrm{u}}$, is $10.5 \%$, the elastic modulus in compression, $E_{\mathrm{m}, \mathrm{C}}$ is $29 \mathrm{GPa}$, and test 2 has the ultimate compressive strength of $2380 \mathrm{MPa}$, the ultimate compressive strain of $11.5 \%$, and elastic modulus in compression of $27 \mathrm{GPa}$. Both curves are very similar, and again they are located in the elastic area of the compressive test. Unlike the tensile test, this time there is a slight plastic plateau above $2000 \mathrm{MPa}$. The compressive test also shows that the CVC NiTi rod is brittle and is practically incapable of plastic deformations, and is therefore unsuitable for strain hardening.

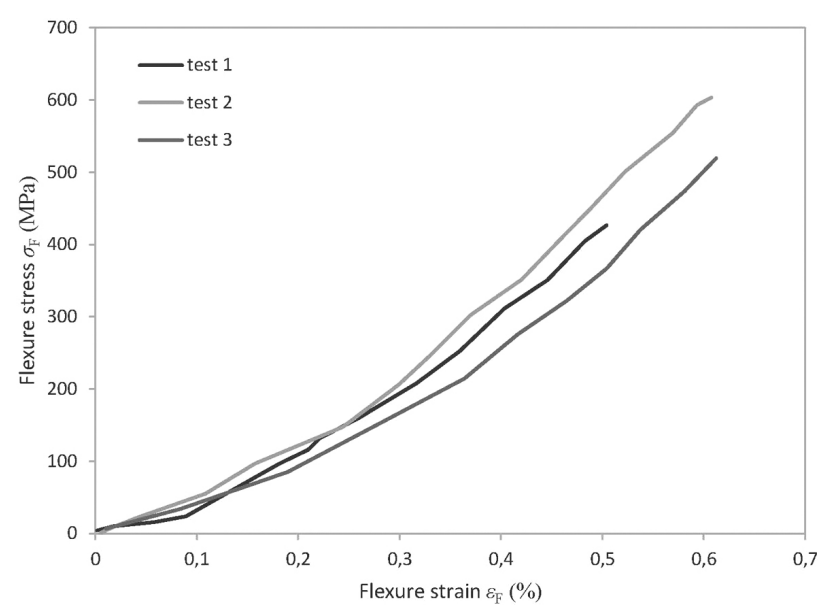

Figure 11: Stress-strain curve for 4-point bending test of three test specimens of CVC NiTi rod 

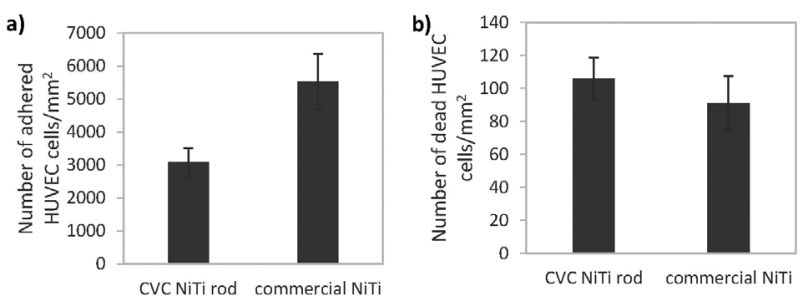

Figure 12: a) Number of adhered HUVEC cells and b) number of dead HUVEC cells

\subsection{4-point bending test}

The 4-point bending diagram in Figure 11 shows predominantly linear curves. As expected, the curves are located in the elastic area. This time the fracture again occurs before the curves reach the area of plastic deformation. Test 1 has the ultimate flexure stress, $\sigma_{\mathrm{F}, \mathrm{u}}$, of $427 \mathrm{MPa}$, ultimate flexure strain, $\varepsilon_{\mathrm{F}, \mathrm{u}}$, of $0.5 \%$ and elastic modulus in flexure, $E_{\mathrm{m}, \mathrm{F}}$, of $113 \mathrm{GPa}$. Test 2 has ultimate flexure stress of $610 \mathrm{MPa}$, ultimate flexure strain of $0.6 \%$ and elastic modulus in flexure of 126 $\mathrm{GPa}$. Test 3 has ultimate flexure stress of $520 \mathrm{MPa}$, ultimate flexure strain of $0.6 \%$ and elastic modulus in flexure of $110 \mathrm{GPa}$.

\subsection{Cytocompatibility}

For the purpose of cytocompatibility measurement, the samples were submersed in a HUVEC cells solution, where the HUVEC cells adhered to the samples surface. HUVEC cells are typical cells in blood vessels, especially veins.

Figure 12a shows the diagram of all the adhered HUVEC cells on the surface of CVC NiTi rod and commercial NiTi. The number of adhered HUVEC cells on the surface of the CVC NiTi rod is $3124 / \mathrm{mm}^{2}$, and on commercial NiTi $5524 / \mathrm{mm}^{2}$. It can be seen that the number of HUVEC cells adhered to the surface of the commercial NiTi is higher than on the surface of the CVC NiTi rod. In Figure 12b, the number of dead HUVEC cells is shown. The number of dead HUVEC cells on the surface of the CVC NiTi rod is $106 / \mathrm{mm}^{2}$, and on commercial NiTi it is $91 / \mathrm{mm}^{2}$.
Optical microscope images (Figure 13a,b) of HUVEC cells on CVC NiTi rod and commercial NiTi show that the cells are arranged individually on both substrates, and they are nowhere grouped together. On commercial $\mathrm{NiTi}$, the cells are much more elongated, while on CVC NiTi rod they are much more scrunched together. In combination with Figure 13c showing a percentage of covered surface area with HUVEC cells, it can be seen that more occupied area with HUVEC cells is on commercial NiTi $(23,1 \%)$, than on the CVC NiTi $\operatorname{rod}(13,2 \%)$.

Commercial NiTi is more cytocompatible than CVC NiTi rod. It has more HUVEC cells adhered to its surface, less dead HUVEC cells and higher proportion of the surface area covered with HUVEC cells. The literature review ${ }^{21-25}$ explains that the growth of cells on the surface of nitinol is influenced by nickel and oxidation of the nitinol surface. The higher the concentration of nickel, the lower are biocompatible properties due to possibility of releasing of $\mathrm{Ni}$ ions that may cause toxic, allergic, and potentially carcinogenic effects, ${ }^{21}$ while biocompatibility can be improved with oxidation, as the $\mathrm{TiO}_{2}$ layer is formed and thus the nickel is removed from the surface. Commercial NiTi (50Ni50Ti) has better biocompatibility due to the fact that it contains less nickel than the CVC NiTi rod (60Ni40Ti).

\section{CONCLUSIONS}

The hardness measurement of the as-cast CVC NiTi rod has revealed that it is very hard $(>550 \mathrm{HV})$, which is influenced by high cooling rates during CVC process and higher nickel content.

The results of the tensile, compressive and bending tests in the form of diagrams evidently showed that the CVC NiTi rod breaks before it passes from the elastic to the plastic region. The CVC NiTi rod is therefore brittle material and cannot be strain hardened.

The biocompatibility test with HUVEC cells showed that more biocompatible is the commercial NiTi because it has more HUVEC cells adhered to its surface, less dead HUVEC cells and higher proportion of the surface area covered with HUVEC cells than CVC NiTi rod.
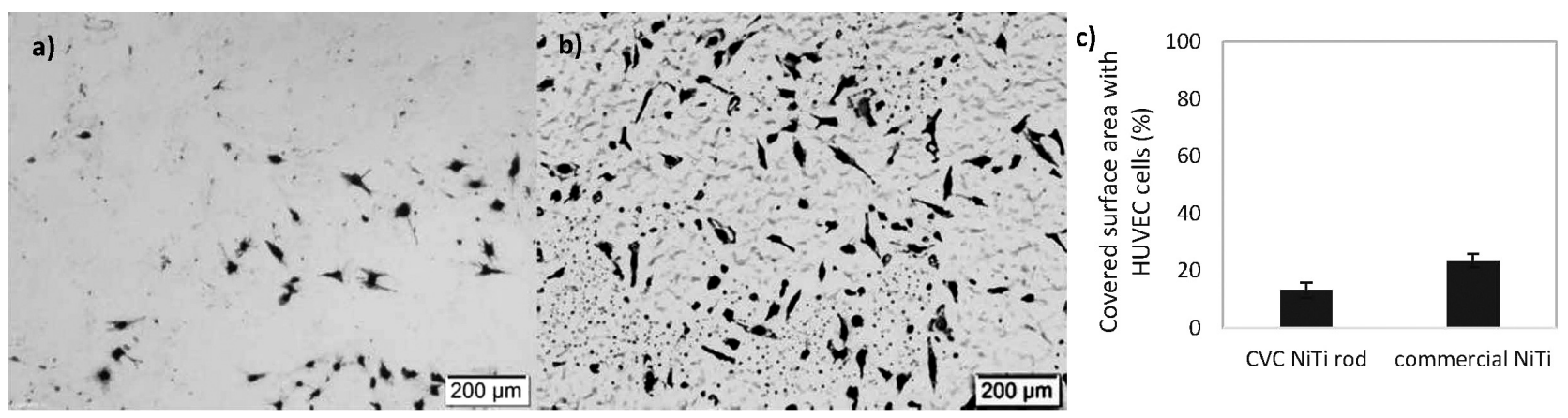

Figure 13: Optical microscope images of HUVEC cells on a) CVC NiTi rod, b) commercial NiTi and c) covered surface area with HUVEC cells 


\section{Acknowledgements}

This work was carried out within the framework of the P2-0132 and L2-5486 of the Slovenian Research Agency and the PhD grant no. 10/2013.

\section{REFERENCES}

${ }^{1}$ R. P. Halani, I. Kaya, Y. C. Shin, H. E. Karaca, Phase transformation characteristics and mechanical characterization of nitinol synthesized by laser direct deposition, Materials Science \& Engineering: A, 559 (2013) 1, 836-843, doi:10.1016/j.msea.2012.09.031

${ }^{2}$ J. Frenzel, Z. Zhang, K. Neuking, G. Eggeler, High quality vacuum induction melting of small quantities of NiTi shape memory alloys in graphite crucibles, Journal of Alloys and Compounds, 385 (2004) 1-2, 214-223, doi:10.1016/j.jallcom.2004.05.002

${ }^{3}$ I. Milošev, B. Kapun, The corrosion resistance of Nitinol alloy in simulated physiological solutions Part 1: The effect of surface preparation, Materials Science and Engineering: C, 32 (2012) 5, 1087-1096, doi:10.1016/j.msec.2011.11.007

${ }^{4}$ C. H. Fu, M. P. Sealy, Y. B. Guo, X. T. Wei, Finite element simulation and experimental validation of pulsed laser cutting of nitinol, Journal of Manufacturing Processes, 19 (2015), 81-86, doi:10.1016/ j.jmapro.2015.06.005

${ }^{5}$ A. Laskovski, ed., Biomedical Engineering, Trends in Materials Science, $1^{\text {st }}$ ed., InTech, Rijeka 2011

${ }^{6}$ W. Simka, A. Sadkowski, M. Warczak, et al., Characterization of passive films formed on titanium during anodic oxidation, Electrochimica Acta, 56 (2011) 24, 8962-8968, doi:10.1016/ j.electacta.2011.07.129

F. Weng, C. Chen, H. Yu, Research status of laser cladding on titanium and its alloys: A review, Materials \& Design, 58 (2014), 412-425, doi:10.1016/j.matdes.2014.01.077

${ }^{8}$ S. Bauer, P. Schmuki, K. von der Mark, J. Park, Engineering biocompatible implant surfaces Part I: Materials and surfaces, Progress in Materials Science, 58 (2013) 3, 263-300, doi:10.1016/j.pmatsci. 2012.09.001

${ }^{9}$ J. Y. Wong, J. D. Bronzino, D. R. Peterson, eds., Biomaterials, Taylor \& Francis Group, Boca Raton, FL 2013

${ }^{10}$ J. R. Davis, ed., Handbook of Materials for Medical Devices, ASM International, Materials Park, OH 2003

${ }^{11}$ H. R. Wang, F. Liu, Y. P. Zhang, D. Z. Yu, F. P. Wang, Preparation and properties of titanium oxide film on NiTi alloy by micro-arc Oxidation, Applied Surface Science, 257 (2011) 13, 5576-5580, doi:10.1016/j.apsusc.2011.01.047

${ }^{12}$ D. Vojtech, M. Voděrová, J. Fojt, P. Novák, T. Kubásek, Surface structure and corrosion resistance of short-time heat-treated NiTi shape memory alloy, Applied Surface Science, 257 (2010) 5 , 1573-1582, doi:10.1016/j.apsusc.2010.08.097

${ }^{13}$ T. Hu, C. Chu, L. Yin, et al., In vitro biocompatibility of titaniumnickel alloy with titanium oxide film by H202 oxidation, Trans.
Nonferrous Met. Soc. China, 17 (2007) 3, 553-557, doi:10.1016/ S1003-6326(07)60132-0

${ }^{14}$ S. A. Shabalovskaya, H. Tian, J. W. Anderegg, D. U. Schryvers, W. U. Carroll, J. van Humbeeck, The influence of surface oxides on the distribution and release of nickel from Nitinol wires, Biomaterials, 30 (2009) 4, 468-477, doi:10.1016/j.biomaterials.2008.10.014

${ }^{15}$ H. Tian, T. Schryvers, D. Liu, Q. Jiang, J. van Humbeeck, Stability of $\mathrm{Ni}$ in nitinol oxide surfaces, Acta Biomaterialia, 7 (2011) 2 , 892-899, doi:10.1016/j.actbio.2010.09.009

${ }^{16}$ A. Stambolić, I. Anžel, G. Lojen, A. Kocijan, M. Jenko, R. Rudolf, Continuous vertical casting of a NiTi alloy, Materiali in tehnologije, 50 (2016) 6, 981-988, doi:10.17222/mit.2016.111

${ }^{17}$ A. Amini, C. Yang, Y. Xiang, Hypothesis on phase transition nucleation and propagation in polycrystalline NiTi shape memory alloys under nanoscale compressive loading, Materials Today: Proceedings, 3 (2016), 708-714, doi:10.1016/j.matpr.2016.01.117

${ }^{18}$ Y. Motemani, M. Nili-Ahmadabadi, M. J. Tan, M. Bornapour, S. Rayagan, Effect of cooling rate on the phase transformation behavior and mechanical properties of Ni-rich NiTi shape memory alloy, Journal of Alloys and Compounds, 469 (2009), 164-168, doi:10.1016/j.jallcom.2008.01.153

${ }^{19}$ O. Benafan, A. Garg, R. D. Noebe, H. D. Skorpenske, K. An, N. Schell, Deformation characteristics of the intermetallic alloy $60 \mathrm{NiTi}$, Intermetallics, 82 (2017), 40-52, doi:/10.1016/j.intermet.2016. 11.003

${ }^{20}$ S. Jiang, Y. Zhang, H. Fan, Fracture behavior and microstructure of as-cast NiTi shape memory alloy, Transactions of Nonferrous Metals Society of China, 22 (2012) 6, 1401-1406, doi:10.1016/S10036326(11)61332-0

${ }^{21}$ J. Huang, P. Dong, W. Hao, T. Wang, Y. Xia, G. Da, Y. Fan, Biocompatibility of $\mathrm{TiO}_{2}$ and $\mathrm{TiO}_{2}$ /heparin coatings on NiTi alloy, Applied Surface Science, 313 (2014), 172-182, doi:10.1016/ j.apsusc.2014.05.182

${ }^{22}$ M. Pohl, T. Glogowski, S. Kühn, C. Hessing, F. Unterumsberger, Formation of titanium oxide coatings on NiTi shape memory alloys by selective oxidation, Materials Science and Engineering A, 481-482 (2008), 123-126, doi:10.1016/j.msea.2007.02.151

${ }^{23}$ J. Huang, J. Wang, X. Su, W. Hao, T. Wang, Y. Xia, G. Da, Y. Fan, Biocompatibility of nanoporous $\mathrm{TiO}_{2}$ coating on NiTi alloy prepared via dealloying method, Journal of Nanomaterials, 2012 (2012), 1-7, doi:10.1155/2012/731592

${ }^{24}$ I. Junkar, M. Kulkarni, B. Drašler, N. Rugelj, N. Recek, D. Drobne, J. Kovač, P. Humpolicek, A. Iglič, M. Mozetič, Enhanced biocompatibility of TiO2 surfaces by highly reactive plasma, J. Phys. D: Appl. Phys., 49 (2016), 1-10, doi:10.1088/0022-3727/49/24/244002

${ }^{25}$ F. López-Huerta, B. Cervantes, O. González, J. Hernández-Torres, L. García-González, R. Vega, A. L. Herrera-May, E. Soto, Biocompatibility and surface properties of $\mathrm{TiO}_{2}$ thin films deposited by DC magnetron sputtering, Materials, 7 (2014), 4105-4117, doi:10.3390/ ma7064105 